\title{
Redescription, new distribution record, DNA sequence and length-weight relationship of the Eel-loach Pangio pangia (Cypriniformes: Cobitidae) in the River Ganges Basin, India
}

\author{
U.K. Sarkar, A. Dabas, G.E. Khan, V.K. Dubey, R. Kumar, A.K. Mishra, A. Pal, S.P. Singh and J.K. Jena \\ National Bureau of Fish Genetic Resources, Canal Ring Road, Dilkusha, Lucknow- 226002, India. Phone: 91 (India)-522-2441735; 2442440, \\ 2442441, Fax: 91 (India)-522-2442403; usarkar1@rediffmail.com, uksarkar1@gmail.com
}

Received 19-IX-2012 Corrected 6-XI-2012 Accepted 30-I-2013

\begin{abstract}
The Eel-loach Pangio pangia has never been reported from East India in the River Ganges. In August, 2011, we collected a total of 39 individuals of this species during fish diversity explorations in River Ganges at Narora. This is the first record for Uttar Pradesh (North India). We present additional diagnostic features and description for this species previously known only from very old descriptions generally based on preserved specimens. Additionally, a molecular signature of the internal transcribed spacer 2 (ITS2) region between $5,8 \mathrm{~S}$ and $28 \mathrm{~S}$ ribosomal RNA genes was sequenced and submitted to NCBI (Accession No. JQ619873). The length-weight relationship showed allometric growth as $b$ value of overall length-weight relation was 2,71 at $p<0,00$ which, ranged from 2,65 to 2,76 . The substantial threats and issues regarding unawareness of this understudied fish species are highlighted to help sustaining fish biodiversity in India.
\end{abstract}

\section{KEY WORDS}

New distribution, Pangio pangia, length weight relationship, River Ganges, India.

\section{RESUMEN}

La ánguila Pangio pangia del río Ganges de las Indias Orientales, nunca había sido reportado para el sitio, resultando en una dificultad para determinar no solamente su localidad, sino también la razón de su extinción en la cuenca del Ganges de la India. En agosto de 2011, registramos un total de 39 individuos de esta especie durante exploraciones de diversidad de peces en el río Ganges en Narora; por primera vez en Uttar Pradesh (norte de India). Las características diagnósticas y la descripción de esta especie han sido actualizadas ya que la información disponible era muy vieja y en general basada en muestras de especímenes preservados. Adicionalmente, como una firma molecular de esta especie se ingresó a NCBI GenBank ( $N$ de Acceso JQ619873) la región interna transcrita espaciadora 2 (ITS2) entre 5,85 y $28 S$ ARN ribosomal. La relación talla-peso mostró un crecimiento alométrico como valor de b, en general la relación talla-peso fue 2,71 ( $p<0,00$ ), que van desde 2,65 a 2,76. Las amenazas sustanciales y cuestiones relativas a la inconsciencia de esta especie poco estudiada fueron destacados para la sostenibilidad de la biodiversidad de peces en la India.

\section{PALABRAS CLAVE}

Nueva distribución, Pangio pangia, relación talla-peso, río Ganges, India.
Loaches of the genus Pangio are small to very small fishes, with an elongate to very elongate body, of 25 species of freshwater fish in the loach family (Cobitidae). The different species inhabit in a variety of habitats ranging from moderately swift to almost standing water, occurring from India and Southern Viet Nam to Java (Kottelat \& Lim, 1996). These species are best represented in the Sunda Islands, where 16 of the species inhabit (Kottelat \& Whitten, 1996). In contrast, only a few eel-loach species are known from India and Myanmar (Blyth, 1860; Günther, 1868; Day, 1872;
1878; Talwar \& Jhingran, 1991; Menon, 1999; Jayaram, 1999). Four species, P. bashai, P. pangia, P. goaensis, and $P$. longipinnis were reported from Kerala, Goa, Northern Bengal, Assam, Manipur and Myanmar from Indawgyi Lake in India (Menon, 1999; Britz \& Maclaine, 2007; Vishwanath, Lakra \& Sarkar, 2007; Jayaram, 2010). Pangio pangia (Hamilton, 1822), considered a valid species (Talwar \& Jhingran, 1991; Jayaram, 2010; Britz \& Maclaine, 2007), was also treated as a synonym of Acanthophthalmus pangia (Hamilton, 1822), Pangia cinnamomea (McClelland, 1839), 
Canthophrys rubiginosus (Swainson, 1839), and Cobitis pangia (Hamilton 1822; Menon, 1999).

In River Ganges in East India, Hamilton (1822) was first to describe Cobitis pangia as a synonym of Pangio pangia, however, the locality of this species was unknown (Froese \& Pauly, 2010). Later the species was placed under the genus Pangio and has been redescribed by Britz and Maclaine (2007). The basin of River Ganges, which has very high cultural, heritage and religious values, drains about $1060000 \mathrm{~km}^{2}$ and it is the fifth largest in the world (Welcomme, 1985). The River Ganges supports an exceedingly rich diversity of freshwater fishes and nutritional security of local people (Sarkar et al., 2011). Current studies revealed that substantial number of species in this River is being shifted and moving upward in the upper stretches of the River due to change in temperature clime and rainfall patterns (Sarkar et al., 2011). We collected P. pangia from the middle stretch of the River Ganges near Narora, Uttar Pradesh which is a new distribution record of this species in this state and after a very long period in River Ganges. The conservation status of this species listed as least concern (LC) as per the FISHBASE and IUCN (2010). In addition, lack of definite information on the abundance, distribution and biological aspects of this species has hampered the planning and management strategies for their conservation.

As far as we know, there is no previous record of $P$. pangia in North India, especially in Uttar Pradesh, the present report may be considered as the first evidence of a broader distributional range of $P$. pangia, indicating that the species may be more widely distributed than previously acknowledged. The length-weight relationship was additionally investigated which could serve as first baseline information for fishery biologists and conservationists. The threats to this species were also discussed.

\section{METHODOLOGY}

The specimens were collected from the middle stretch of the River Ganges near Narora $\left(28^{\circ} 11,305 \mathrm{~N}\right.$, $078^{\circ} 23,797 \mathrm{E}$ ) about $170 \mathrm{~km}$ from New Delhi, capital of India (Fig. 1). The specimens were collected using a cast net during an experimental shoreline fishing operation in August, 2011. All the samples were transported to the laboratory where they were identified following Talwar and Jhingran (1991) and Jayaram (2010). The specimens were subsequently counted and a total of twelve

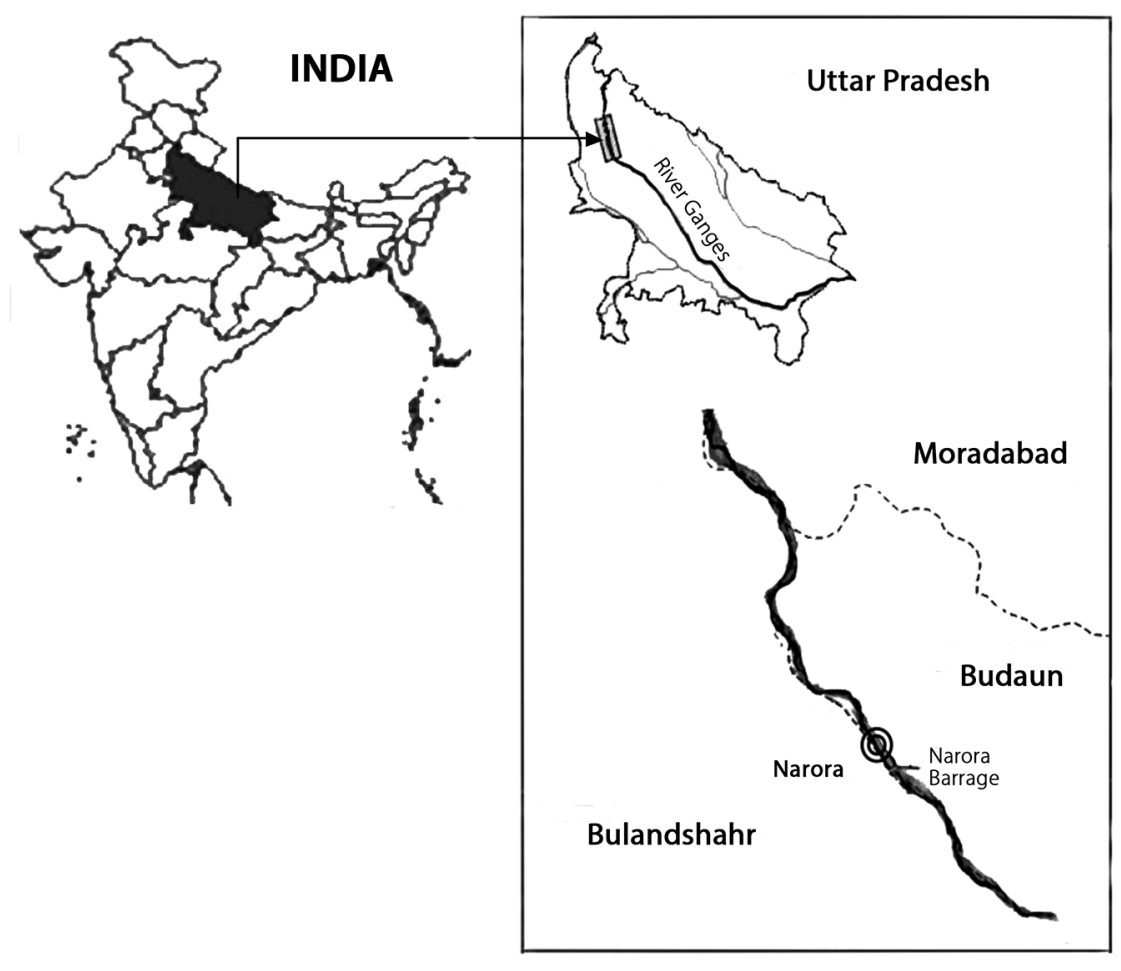

FIG. 1. Drainage map of River Ganges with sampling location at Narora. 
TABLE 1

Distribution records of the genus Pangio in India.

\begin{tabular}{|c|c|c|c|c|}
\hline SN & Species & Distribution & $\begin{array}{l}\text { Occurrence } \\
\text { locations }\end{array}$ & References \\
\hline 1 & Pangio bashai (Easa \& Shaji) & Silent valley, Kerala & 1 & Easa and Shaji, 1997 \\
\hline 2 & Pangio goaensis (Tilak, 1972) & $\begin{array}{l}\text { Colem river (Goa), Chaliyar } \\
\text { river (Kerala), Manimala } \\
\text { river (South Kerala) }\end{array}$ & 3 & $\begin{array}{l}\text { Gopala,Krishnan \&Ponniah, 2000; } \\
\text { Menon, 1999; Kapoor et al., 2002; } \\
\text { Talwar \& Jhingran,1991; Shaji } \\
\text { et al., 2000, Thomas et al., 1999; } \\
\text { Dahanukar et al.,2004 }\end{array}$ \\
\hline 3 & Pangio longipinnis (Menon, 1992) & $\begin{array}{l}\text { Manipur, Kharangpat Lake, } \\
\text { South of Imphal }\end{array}$ & 3 & Menon, 1999 \\
\hline 4 & Pangio pangia (Hamilton, 1822) & Assam, Manipur, NE Bengal & 3 & $\begin{array}{l}\text { Britz \& Maclaine, 2007; Menon, } \\
\text { 1999; Kapoor et al., } 2002\end{array}$ \\
\hline
\end{tabular}

morphometric and meristic characters were taken with a Mitutoyo digital caliper to the nearest $0,01 \mathrm{~mm}$ (Table 1). A digital photograph of the specimen was taken, and it was then fixed in 10\% formaldehyde for further studies. Physical and chemical parameters of the site were also collected (water temperature, conductivity, $\mathrm{pH}$, total dissolved solids, and dissolved oxygen) using YSI multiparameter sonde. Water velocity was measured by flow meter (JDC Electronics SA, Switzerland).

The statistical relationship between total length (TL) and total body weight (TBW) of the fishes was derived using the formula:

$$
\log W=\log a+b \log L
$$

Where $W=$ weight of fish in grams, $a=$ intercept (constant), $L=$ length of fish in centimeters and $b=$ regression coefficient (slope).

All data were log-transformed and the ensuing least squares linear regressions (Zar, 1984) performed by GRAPHPAD PRISM 5.0, with the weight as the dependent variable. A linear regression on log-transformed data was highly significant $(\mathrm{p}<0,00)$ for $P$. pangia.

Internal Transcribed Spacer 2 (ITS2) of ribosomal DNA is regarded as one of the candidate DNA barcode because it possesses a number of valuable characteristics, such as the availability of conserved regions for designing universal primers, the ease of its amplification and sufficient variability to distinguish even closely related species. The success rates for using the ITS2 region to identify dicotyledons, monocotyledons, gymnosperms, ferns, mosses and animals were $76,1 \%, 74,2 \%, 67,1 \%$, $88,1 \%, 77,4 \%$ and $91,7 \%$ respectively at the species level (Yao et al., 2010).

\section{RESULTS}

\section{Diagnostic}

Morphometric and meristic details of P. pangia (Fig. 2) are presented in Table 2. The average total length of 39 specimens was $50,41 \mathrm{~mm}$ which ranged between 44,2 to $62,2 \mathrm{~mm}$ with average body depth $5,64 \mathrm{~mm}$. The fin formula comprised: $\mathrm{D}$ ii $6 / \mathrm{A}$ ii $5 / \mathrm{P}$ i $6 / \mathrm{V}$ i 4 . Head was very short and its length measured 3,34 times in head width. Standard length was $8,16 \pm 0,14$ times in body depth. Eyes were minute, covered by skin, in middle of head. Head length measured 9,03 $\pm 0,11$ times in eye diameter. Dorsal fin was short inserted in posterior half of body, nearer caudal fin base than tip of snout. Predorsal length was measured 2,78 times in post dorsal length.

\section{Description}

Body elongate strongly, compressed and anguilliform. Head deeply compressed. Eyes minute. Mouth small and inferior, lips thick, lower lip with two contiguous prolongations. Three pairs of barbels. Dorsal fin small. Caudal fin truncate. Scales minutely embedded in skin and the fresh specimens were uniformly reddish brown in color.

\section{Remarks}

Due to very smooth and soft body the species often become twisted and easily disformed even in best prepared collections. The species are often difficult to measure with accuracy, thus, careful handling of the samples is recommended at the time of collection. 


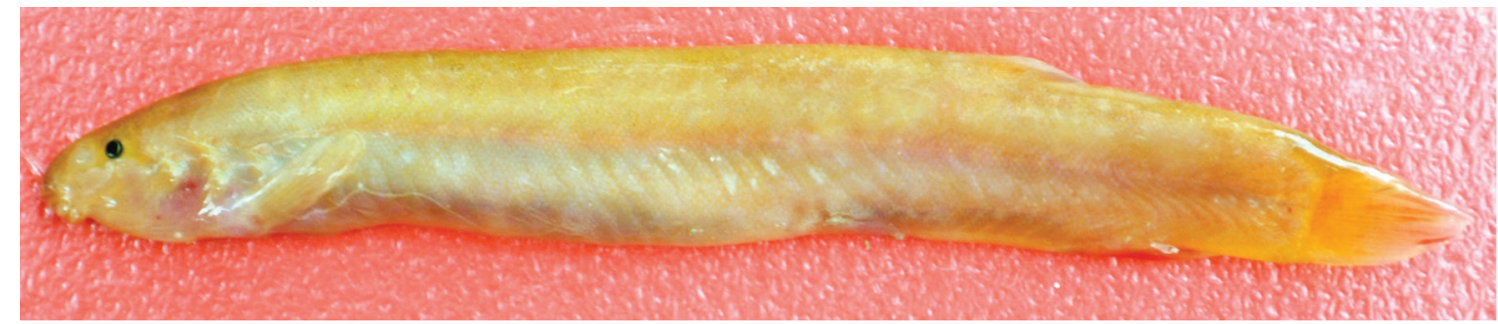

FIG. 2. Lateral view of Pangio pangia (47,41 mm SL).

Color version of this photograph, available at: http://investiga.uned.ac.cr/revistas/index.php/cuadernos/index.

TABLE 2

Morphometric and meristic details of Pangio pangia $(n=39)$, collected from River Ganges, India

\begin{tabular}{lcc}
\hline \multicolumn{1}{c}{ Morphometric variables } & $\begin{array}{c}\text { Average length } \\
\pm \text { SE (mm) }\end{array}$ & Ranges (mm) \\
\hline Total length & $50,41 \pm 0,81$ & $44,2-62,2$ \\
Standard length & $45,54 \pm 0,76$ & $39,3-56,1$ \\
Body depth & $5,64 \pm 0,13$ & $4,4-6,9$ \\
Relative charterers: & & \\
Standard length/body depth & $8,16 \pm 0,14$ & $39,3-56,1 / 4,4-6,9$ \\
Standard length/head length & $8,25 \pm 0,06$ & $39,3-56,1 / 4,9-7,4$ \\
Head length/eye diameter & $9,03 \pm 0,11$ & $4,9-7,4 / 0,5-0,8$ \\
Inter orbital width/eye diameter & $2,20 \pm 0,02$ & $1,2-1,6 / 0,5-0,8$ \\
Head length/head width & $3,34 \pm 0,02$ & $4,9-7,4 / 1,5-2,0$ \\
Head length/mouth width & $8,29 \pm 0,13$ & $4,9-7,4 / 1,2-1,6$ \\
Pre-dorsal length/ Post-dorsal length & $2,78 \pm 0,06$ & $3,1-4,8 / 29,4-41,9$
\end{tabular}

\section{Habitat}

The collection site has a moderate flow $\left(0,06 \mathrm{~ms}^{-1}\right)$ with leteral scour pools and riffles. Substrate was mostly cobbles (80\%) and gravels (40\%). The stream bank was stable, and its mean width was measured $45 \mathrm{~m}$ and depth $0,92 \mathrm{~m}$. Scattered shrubs and mid-story trees were the canopy cover. Based on the habitat parameters, the site was considered a mid-reach stream. Water was muddy due to heavy rainfall in the monsoons. Dissolved oxygen was measured $7 \mathrm{mg} / \mathrm{l}$, temperature, $29,12^{\circ} \mathrm{C}$, conductivity $0,087 \mathrm{~m} / \mathrm{mhos}$ and total hardness, $28 \mathrm{mg} / \mathrm{l}$.

\section{Length-weight relation}

This is the first information on the length weight relationship of $P$. pangia. The curves obtained by plotting weight against the length for specimens of $P$. pangia revealed curvilinear nature (Fig. 3). The calculated coefficient of correlation between body length and weight was 0,996 showing a high degree of correlation. In the present study, the estimates of parameter $b$ ranged from 2,65 to 2,76 and b value of overall length-weight relation was 2,71 showing allometric growth. The figure also shows that the weight of fish increased as an exponential function of its length.

\section{Molecular identification}

A 337bp long consensus DNA sequence, containing partial 5,8S, complete Internal Transcribed Spacer 2 (ITS2) and partial 28S ribosomal gene regions, was generated by aligning forward and reverse sequences obtained after amplification obtained using primers ITS2 F4 (5'-GCTACGCCTGTCTGAGGGTCGCT-3') and ITS2 R4 


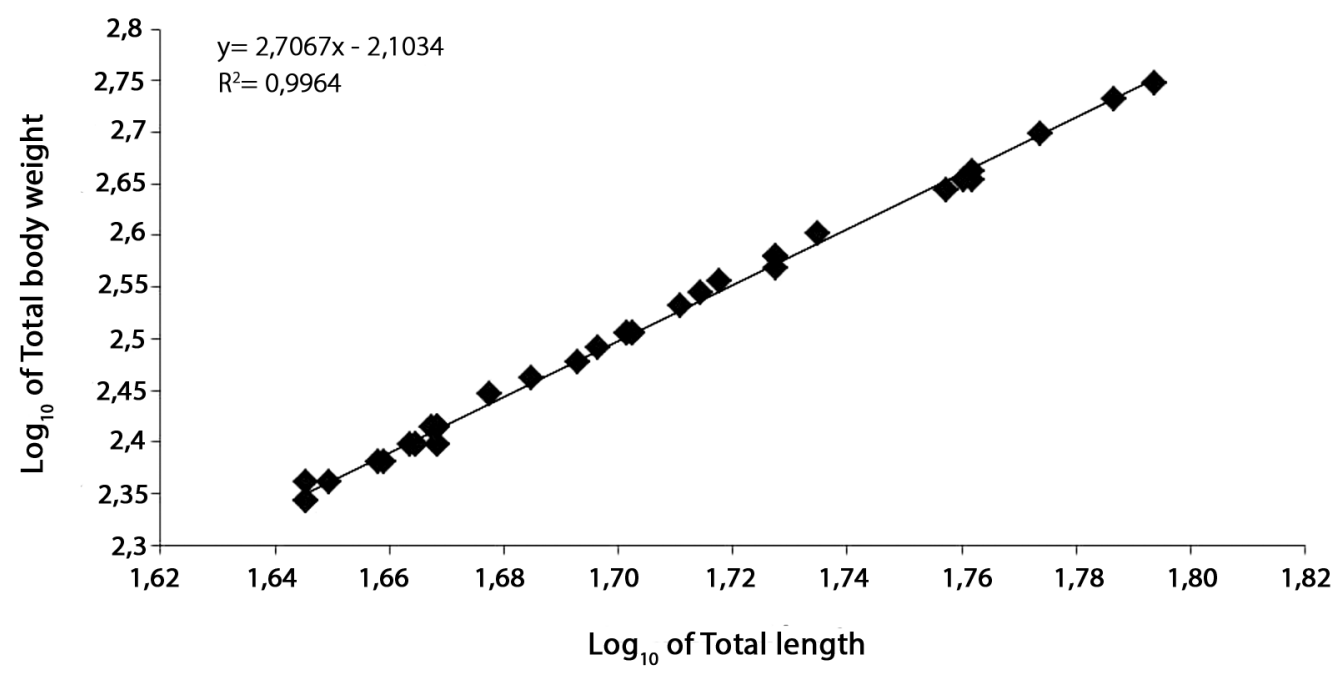

FIG. 3. Regression plot representation of length weight relationship for Pangio pangia.

(5'-TTCAGCGGGTCGTCTCGTCTGATC-3'). The sequence was submitted to NCBI (Accession no. JQ619873).

\section{DISCUSSION}

Inadequate knowledge about abundance and distribution of species confines not only our understanding of the ecological and evaluative processes but also affect our capacity to use this information in conservation management plans (Maitland, 1995). P. pangia Hamilton, described in 1822 in River Ganges has never been reported subsequently (Table 1), though many of the fish diversity studies carried out by several authors in River Ganges and its tributaries (Srivastava, 1980; Ravenga \& Mock, 2000; Sinha, 2007; Sarkar \& Bain, 2007; Sarkar, Gupta \& Lakra, 2010; Lakra, Sarkar, Kumar, Pandey, Dubey \& Gusain, 2011; Sarkar et al., 2011). Moreover, various other investigators; Banarescu and Nalbant (1968), Talwar and Jhingran (1991), Menon (1999), Kottelat (1996) and Jayaram (1999) also documented $P$. pangia, while these information did not provide distributional data, or specimens voucher locations except a recent study by Vishwanath et al. (2007) who reported this species from the drainages of Myanmar.

In view of the above that we reported this species in River Ganges after a very long period therefore, our recent record of this species suggests the population of $P$. pangia to be in a precarious state which emphasized the first distribution record of this species in North India of the River Ganges. From a taxonomic point of view, the genus
Pangio is also important while, only four species were documented in India. It is interesting to know that as the species has never reported at this stretch of River Ganges, thus the current record revealed the possibilities due to climate change since other current studies showed perceptible shifts in many of the freshwater fishes (Sarkar et al., 2011). Additionally, our present findings unwrapped the possibility for new distribution records of $P$. pangia and other species of this genus.

Growth of fish usually indicated through increase in length and weight (Jobling, 2002) which is the most appropriate characteristic to determine the population analysis at a particular time. So far our knowledge, this is the first report on the length weight relationship of $P$. pangia. The exponential value of the length-weight relationship ' $b$ ' in $P$. pangia followed the cube law especially the pooled data (' $b$ ' $=2,71$ ), indicating thereby an allometric pattern of growth in the fish. According to Hile (1936) and Martin (1949) the value of 'b' usually remains constant at 3,0 for an ideal fish. However, Beverton \& Holt (1957) suggested the departure of the ' $b$ ' value from 3 is rare in adult fishes. The $b$ values obtained in the present work conform with those of earlier researchers who have estimate the $b$ value in various fish species, e.g. Ahmed and Saha (1996) and Sarkar, Deepak and Negi (2009) in the Ganga basin; Ramakrishniah (1988) in Nagarjunasagar reservoir, India; and Pet, Gevers, van Densen and Vijverberg. (1996) in Sri Lankan reservoirs. Presently, there are no studies done on the freshwater fish P. pangia on the length-weight relationship thus, our findings are advantageous for better 
understanding on factors influencing fish growth in various habitats in north Indian water bodies.

The exploitation of natural resources threatens $P$. pangia. The fishermen are not much aware of this species and caught as by-catch when netting for small sized fishes. Because their body is very smooth and easily disformed therefore, it is very difficult to handle and kept as live while netting. Barrages and pollution from industrial sewage from thermal power plant at Narora were the major threat to this species. Cultivation of water chesnut at the sampling site was also observed which destroy the habitat of $P$. pangia and threatens its survival. There are also problems with catchment mismanagement. Unfortunately, scarce knowledge about this species has mired their conservation and management plans in India.

In conclusion, our first record of this species revealed the uncertainty that whether the population of this species is resident in River Ganges or not. Therefore, more exploration in the streams and Rivers of the Ganges basin at various spatial scales are to be encouraged for the better understanding of their habitat. As there is no study on molecular taxonomy of this species therefore there is also a need to characterize the population, using morphological and molecular tools. Additionally, our study has provided the first basic and baseline information on the length-weight relationships of $P$. pangia from the Ganges River that would be beneficial for fishery biologists and conservationists to impose adequate regulations for sustainable fishery management of this understudied fish.

\section{ACKNOWLEDGEMENT}

The authors thanks the Director, National Bureau of Fish Genetic Resources, Lucknow for providing the necessary facilities and suggestions. The authors are also indebted to the Uttar Pradesh State Biodiversity Board (UPSBB), Lucknow; Government of Uttar Pradesh, India for providing financial assistance to carry out the exploration.

\section{REFERENCES}

Ahmed, K.K. \& Saha, S.B. (1996). Length-weight relationships of major carps in Kapati Lake, Bangladesh. Naga ICLARM Q, 19-22.

Banarescu, P., Nalbant, T.T. (1968). Cobitidae (Pisces, Cypriniformes) collected by the German India expedition. Mitteilungen Hamburgisches Zoologisches Museum und Institute, 65, 327- 35.
Beverton, M.A. \& Holt, S.J. (1957). On the dynamics of exploited fish populations, U.K. Ministry of Agriculture and Fisheries. Fisheries Investigation Series, 19, 533.

Blyth, E. (1860). Report on some fishes received chiefly from the Sittang River and its tributary streams. Journal of Asiatic Society Calcutta, 29, 138-174.

Britz, R. \& Maclaine, J. (2007). A review of the eel-loaches, genus Pangio, from Myanmar (Teleostei: Cypriniformes: Cobitidae). Ichthyological Exploration of Freshwaters, 18, 17-30.

Dahanukar, N., Raut, R. \&. Bhat, A. (2004). Distribution, endemism and threat status of freshwater fishes in the Western Ghats of India. Journal of biogeography, 31, 123-136.

Day, F. (1872). Review of the Indo-Pacific Doryrhamphine pipefish genus Doryichthys. Japanese Journal of Ichthyology, $28,1-18$.

Day, F. (1878). The fishes of India: being a natural history of the fishes known to inhabit the seas and fresh waters of India. London, England: Burma and Ceylon.

Easa, P.S. \& Shaji, C.P. (1997). Freshwater fish diversity in Kerala part of the Nilgiri biosphere reserve. Current Science, 73(2), 180-182.

Froese, R. \& Pauly, D. (2010). FishBase. World Wide Web electronic publication. Retrieved from http://www fishbase. org, version.

Günther, A. (1868). Catalogue of the fishes in the British Museum. Volume VII. London, England: Trustees of the British Museum.

Hamilton, F. (1822). An account of the fishes found in the River Ganges and its branches. Edinburgh, UK: Constable and Co.

Hile, R. (1936). Age and growth of Leucicthys artedi in the lakes of the northeastern Himalayan mahseer with reference to its fishery. Indian. Journal of Animal Science, 55(1), 65-70.

IUCN. (2010). IUCN Red List of Threatened Species (ver. 2010.4). Retrieved from http://www.iucnredlist.org

Jayaram, K.C. (2010). The freshwater fishes of the Indian region. Delhi, India: Narendera Publishing House.

Jayaram, K.C. 1999. The freshwater fishes of the Indian region. Delhi, India: Narendra Publishing House.

Jobling, M. (2002). Environmental factors and rates of development and growth. In Handbook of Fish Biology and Fisheries. Oxford, U.K: Blackwell Publishing.

Kottelat, M. \& Whitten, T. (1996). Freshwater biodiversity in Asia, with special reference to fish. World Bank Technical Papper. Retrieved from http://books.google. co.cr/books/about/Freshwater_biodiversity_in_Asia. html?id=SOcUBjfhSOQC\&redir_esc $=y$

Lakra, W.S., Sarkar, U.K., Kumar, R.S., Pandey, A., Dubey, V.K. \& Gusain, O.P. (2011). Fish diversity, habitat ecology and their conservation and management issues of a tropical River in Ganga basin. India. Environmentalist, 30(4), 306-319. 
Maitland, P.S. (1995). The conservation of freshwater fish: past and present experience. Biological Conservation, 72, 259-270.

Martin, W.R. (1949). The mechanics of environmental control of body form in fishes. University of Toronto studies in Biological Series, 58(70), 1-72.

McClelland, J. (1839). Indian Cyprinidae. 19. Asiatic research. Culcutta: Bishop College press.

Menon, A.G.K. (1999). Check list - fresh water fishes of India. Records of the Zoological Survey of India. Miscellaneous Publications Occas 175, 366.

Pet, J.S., Gevers, G.J.M., van Densen, W.L.T. \& Vijverberg, J. (1996). Management options for a more complete utilization of the biological fish production in Sri Lankan reservoirs. Ecology of Freshwater Fish, 5, 1-14.

Ramakrishniah, M. (1988). Age, growth and fishery of Mystus aor (Hamilton) from Nagarjuasagar reservoir. In The first indian fisheries forum proceedings. India, Mangalore: Asian Fisheries Society.

Revenga, C. \& Mock, G. (2000). Pilot Analysis of global ecosystems: freshwater systems and world resources 1998-99. Washington, DC, USA: World Resources Institute.

Sarkar, U.K. \& Bain, M.B. (2007). Priority habitats for the conservation of large River fishes in the Ganges River basin. Aquatic Conservation: Marine and Freshwater Ecosystems, 17, 349-359.

Sarkar, U.K., Deepak, P.K. \& Negi, R.S. (2009). Length-weight relationship of clown knifefish Chitala chitala (Hamilton, 1822) from the River Ganga basin, India. Journal of Applied Ichthyology, 25, 232-233.

Sarkar, U.K., Gupta, B.K. \& Lakra, W.S. (2010). Biodiversity, ecohydrology, threat status and conservation priority of the freshwater fishes of River Gomti, a tributary of River Ganga (India). Environmentalist, 30(1), 3-17.
Sarkar, U.K., Pathak, A.K., Sinha, R.K., Sivakumar, K., Pandian, A.K., Pandey, A., Dubey, V.K. \& Lakra, W.S. (2011). Freshwater fish biodiversity in the River Ganga (India): changing pattern, threats and conservation perspectives. Reviews in Fish Biology and Fisheries, 22, 251-272.

Sinha, R.K. (2007). Ecological basis for management and conservation of Riverine fisheries with special reference to the Ganga River system. In River fisheries in India, issues and current status. Barrackpore, India: Inland Fisheries Society of India.

Srivastava, G.J. (1980). Fishes of Uttar Pradesh and Bihar. Varanasi, India: Vishwavidyalaya Prakashan.

Swainson, W. (1839). The natural history and classification of fishes, amphibians, \& reptiles, or monocardian animals. Londres Natural History \& Class, 2(i-vi), 1-448.

Talwar, P.K. \& Jhingran, A.G. (1991). Inland fishes of India and adjacent countries. Vol 1. A.A. Balkema, Rotterdam: Oxford \& IBH Pub. Co

Thomas R. (1999). Distribution of Pangiogoaensis (Tilak) Cypriniformes; Cobitidae, in Manimala River, Southern Karala.

Vishwanath, W., Lakra, W.S. \& Sarkar, U. K. (2007). Fishes of North East India. Lucknow, India: National Bureau of Fish Genetic Resources.

Welcomme, R.L. (1985). River fisheries. FAO Fisheries Technical Paper.

Yao, H., Song, J., Liu, C., Luo1, K., Han, J., Li, Y., Pang, X., Xu, H., Zhu, Y., Xiao, P. \& Chen, S. (2010). Use of ITS2 Region as the Universal DNA Barcode for Plants and Animals. PLOS ONE, 5(10), e13102.

Zar, J.H. (1984). Biostatistical analysis. New Jersey, USA: Prentice Hall. 